\title{
EML4/ALK Fusion Gene Variant 3b
}

National Cancer Institute

\section{Source}

National Cancer Institute. EML4/ALK Fusion Gene Variant 3b. NCI Thesaurus. Code C99729.

A fusion gene $(\sim 2.5 \mathrm{~kb})$ that results from a chromosomal inversion inv(2)(p21p23) which fuses exon $6 \mathrm{~b}$ of the EML4 gene with exons 20-29 of the ALK gene. This fusion is associated with non-small cell lung cancer. Multiple transcript variants are possible based on the breakpoint for the EML4 gene. 